\title{
ENHANCED BIOREMEDIATION OF n-ALKANE IN PETROLEUM SLUDGE \\ USING BACTERIAL CONSORTIUM AMENDED WITH RHAMNOLIPID AND MICRO-NUTRIENTS
}

K.S.M. Rahman*, Thahira J.Rahman, Y. Kourkoutas, I. Petsas and I.M. Banat

Biotechnology Research Group, School of Biological and Environmental Sciences, University of Ulster, Coleraine - BT52 1SA, Northern Ireland, UK

* Corresponding author's present address

Dr Pattanathu K.S.M. Rahman

Chemical and Bioprocess Engineering Group

School of Science and Engineering

Teesside University, Middlesbrough - TS1 3BA

Teesvalley, United Kingdom.

Tel: $\quad+44-1642-384669$

Email: p.rahman@tees.ac.uk 


\begin{abstract}
The purpose of the present study was to investigate possible methods to enhance the rate of biodegradation of oil sludge from crude oil tank bottom, thus reducing the time usually required for bioremediation. Enhancement of biodegradation was achieved through bioaugmentation and biostimulation. $10 \%$ and $20 \%$ sludge contaminated sterile and nonsterile soil samples were treated with bacterial consortium, rhamnolipid biosurfactant and NPK (Nitrogen, Phosphorus and Potassium) solution. Maximum extent of $n$-alkane degradation occurred in the $10 \%$ sludge contaminated soil samples. The effects of treatment carried out with the non-sterile soil samples were more pronounced than in its sterile counterpart. Maximum degradation was achieved after the $56^{\text {th }}$ day of treatment. $n$-alkanes in the range of nC8-nC11 were degraded completely followed by nC12-nC21, nC22-nC31 and nC32-nC40 with the percentage of degradation being 100\%, 83-98\%, 80-85\% and 57-73\% respectively. Statistical analysis using Analysis of Variance (ANOVA) and Duncan's Multiple Range test (DMRT) revealed that the level of amendments, incubation time and combination of amendments significantly influenced bacterial growth, protein concentration and surface tension at a $1 \%$ probability level. All tested additives bacterial consortium, NPK and Rhamnolipid biosurfactant had significant positive effects on the bioremediation of n-alkane in petroleum sludge.
\end{abstract}

Key words: Tank bottom sludge; Bacterial consortium; Rhamnolipid; Bioremediation; Bioaugmentation. 


\section{Introduction}

Petroleum hydrocarbon continues to be used as the principle source of energy and hence an important global environmental pollutant. Apart from accidental contamination of ecosystem, the vast amounts of oil sludge generated in refineries from water oil separation systems and accumulation of waste oily materials in crude oil storage tank bottoms pose great problems because of the expensive disposal methods (Ferrari et al., 1996; Vasudevan and Rajaram, 2001). Despite decades of research, successful bioremediation of petroleum hydrocarbon contaminated soil remains a challenge. Petroleum is a complex mixture of nonaqueous and hydrophobic components like n-alkane, aromatics, resins and asphaltenes. Bioavailability might be the limiting factor controlling the biodegradation of such compounds.

Biosurfactants are amphiphilic compounds that reduce surface and interfacial tensions by accumulating at the interface of immiscible fluids or of a fluid and a solid and increase the surface areas of insoluble compounds leading to increased mobility, bioavailability and subsequent biodegradation. They are produced by many bacterial strains that can degrade or transform the components of petroleum products. They are non-toxic, non hazardous, biodegradable and environmentally friendly compounds (Banat et al., 2000), which may be produced cost effectively under ex-situ conditions, in-situ production may be stimulated at the site of contamination and can be recovered and recycled (Moran et al., 2000). There has been recent successful reports on using them in enhanced oil recovery and in the release of bitumen from tar sands (Mulligan et al., 2001). Hence, reclamation of petroleum hydrocarbon polluted sites can be carried out by bioremediation, which is an enhanced natural process of biodegradation using biosurfactant producing and oil degrading bacterial cultures. Bioremediation technologies generally aim at providing favourable conditions of aeration, 
temperature and nutrients to enhance biological hydrocarbon breakdown (Rahman et al., 2001a). In the present study, we investigated the effect of rhamnolipid biosurfactant (RL) produced by a Pseudomanas aeruginosa strain and addition of nutrients such as nitrogen, phosphorus and potassium (NPK) and a bacterial consortium (BC) to augment natural fertility of the polluted site and enhance bioremediation of crude oil tank bottom sludge (TBS).

\section{Methods}

\subsection{Soil and microbial cultures preparation}

Seashore sand samples from the Portrush coastal area of Northern Ireland and garden soil from University of Ulster campus were collected. Both were sieved using a $1 \mathrm{~mm}$ sieve and used at 1:1 ratio for the preparation of a composite soil sample. Part of the soil was sterilized in hot air oven at $180^{\circ} \mathrm{C}$ for $2 \mathrm{~h}$ and a part kept as normal condition (non-sterile). An oil degrading bacterial consortium containing five strains (Micrococcus sp. GS2-22 (21.7 \pm 1.4 x $10^{5} \mathrm{CFU} / \mathrm{ml}$ ), Bacillus sp. DS6-86 (30.3 $\left.\pm 0.9 \times 10^{5} \mathrm{CFU} / \mathrm{ml}\right)$, Corynebacterium sp. GS5-66 $\left(27.4 \pm 4.7 \times 10^{5} \mathrm{CFU} / \mathrm{ml}\right.$, Flavobacterium sp. DS5-73 (18.9 $\left.\pm 3.6 \times 10^{5} \mathrm{CFU} / \mathrm{ml}\right)$ Pseudomonas sp. DS10-129 (32.6 $\left.\pm 0.8 \times 10^{5} \mathrm{CFU} / \mathrm{ml}\right)$ previously isolated on hydrocarbon containing medium were inoculated in $200 \mathrm{ml}$ of nutrient broth and kept in a shaker for $24 \mathrm{~h}$ at room temperature. The strain name with GS was isolated from gasoline station and DS from diesel station soils followed by its strain number were depicted in our strains. Members of the bacterial consortium were selected depending on their efficiency of crude oil degradation (Rahman et al., 2002b). For the preparation of amendments, the rhamnolipid produced by a Pseudomonas aeruginosa strain available at University of Ulster was used. 


\subsection{Preparation of Amendments}

To both sterile (sterilized in an oven at $180^{\circ} \mathrm{C}$ for $3 \mathrm{~h}$ ) and non-sterile soil samples $10 \%$ and $20 \%$ of tank bottom sludge (TBS) with $87.4 \%$ of oil and grease at pH 6.7 was added and mixed thoroughly. To find out the role of indigenous microbial populations present in soil and tank bottom sludge, controls were set up with sterile and nonstrile soil with no amendments. Other amendments containing bacterial consortium, NPK solution and rhamnolipid were set up to test the effects of these additives on biodegradation (Table 1). The treatments were all set-up in sets of screw cap glass universal bottles as microcosms containing $10 \mathrm{~g}$ of soil samples and moisture content was adjusted at $12 \%$. All microcosm tubes were incubated at $30^{\circ} \mathrm{C}$. Triplicate sets of experimental samples were analysed at $0,28,56$ and 84 days to enumerate total heterotrophic bacterial counts, protein content, percentage of n-alkane degradation, $\mathrm{pH}$ and surface tension (ST) were analysed.

\subsection{Enumeration of bacterial population}

Total heterotrophic bacteria were enumerated by using a pour plate technique on plate count agar (Merck, UK) after $24 \mathrm{~h}$ incubation at $30^{\circ} \mathrm{C}$, which also allowed growth of all members of the added bacterial consortium.

\subsection{Total Protein Estimation}

For the estimation of total protein, $1 \mathrm{ml}$ supernatant without any soil particle was taken from soil:water mixture (1:10 ratio). It was centrifuged at $13000 \mathrm{rpm}$ for $10 \mathrm{~min}$ and to the pellet obtained was added $1 \mathrm{ml}$ of a $3 \mathrm{~N} \mathrm{NaOH}$ solution and boiled for $3 \mathrm{~min}$. After cooling at room temperature, $1 \mathrm{ml}$ of a $1 \mathrm{M} \mathrm{H}_{3} \mathrm{PO}_{4}$ solution was added. $50 \mu \mathrm{L}$ was taken and mixed with $950 \mu \mathrm{L}$ Coomassie reagent and incubated at $30^{\circ} \mathrm{C}$ for $10 \mathrm{~min}$ and the optical density was 
measured at $595 \mathrm{~nm}$ using UV - visible spectrophotometer (Shimadzu model number UV 2101PC). The total protein was estimated using a standard curve prepared with albumin (Bradford, 1976).

\subsection{Surface tension analysis}

The surface tension of the soil extract (soil: water ratio is 1:10) was measured using a digital tensiometer (Kruss digital tensiometer model no. K9) equipped with a $6 \mathrm{~cm}$ De Nuoy platinum ring. To increase the accuracy, average of triplicates was used for the study.

\subsection{Measurement of $\mathrm{pH}$}

The $\mathrm{pH}$ of the soil extract (soil:water ratio 1:10) was estimated using Microcomputer $\mathrm{pH}$ meter model 6171.

\subsection{Hydrocarbon estimation}

The hexane soluble n-alkanes (nC8-nC40) in the soil samples were determined using Gas chromatography. Soil and Hexane (1:100 ratio) were mixed for 5 minutes in a vortex mixture and soil free hexane extract was separated using membrane filter and was used for GC analysis. A capillary column (30 m Fused Silica column, Restek Corporation, USA) and GC (Perkin-Elmer 8310) with Flame Ionisation Detector were used for analysis. The injection temperature was $250^{\circ} \mathrm{C}$; detector temperature $250^{\circ} \mathrm{C}$; column temperature was programmed as $50^{\circ} \mathrm{C} / 4 \mathrm{~min}$ then increased at the rate of $10^{\circ} \mathrm{C} / \mathrm{min}$ to $330^{\circ} \mathrm{C}$ and maintained at $330^{\circ} \mathrm{C}$ for 20 minutes. Total recoverable petroleum hydrocarbon standard with purity of $99.9999 \%$ (to detect nC8-nC40) obtained from Restek Corporation, USA was used to identify the n- 
alkanes. Degradation was estimated as the difference between the initial and final concentrations of the n-alkane fractions.

\subsection{Statistical analysis}

The experiment was set up as a factorial design consisting of two concentrations they were $10 \%$ and $20 \%$ sludge contaminated soil x 10 treatments; 1) NS+TBS, 2) NS+TBS+RL, 3) NS+TBS+NPK, 4) NS+TBS+BC, 5) NS+TBS+RL+NPK+BC, 6) SS+TBS, 7) SS+TBS+RL, 8) $\mathrm{SS}+\mathrm{TBS}+\mathrm{NPK}, 9) \mathrm{SS}+\mathrm{TBS}+\mathrm{BC}, 10) \mathrm{SS}+\mathrm{TBS}+\mathrm{RL}+\mathrm{NPK}+\mathrm{BC} \times$ four time periods $(0,28$, 56 \& 84 days) $x$ three replicates per treatment. Statistical analysis was carried out using Analysis of Variance (ANOVA). Mean of the various treatments were tested for level of significance at $1 \%$ and $5 \%$ probability by Duncan's multiple range test (DMRT) (Gomez and Gomez, 1984).

\section{Results and Discussion}

\subsection{Effect of bacterial growth on biodegradation}

Sandy soil was used along with garden soil to increase the porosity and thus aeration for enhanced bioremediation. An initial bacterial population of about $2.1 \pm 0.7 \times 10^{3} \mathrm{CFU} / \mathrm{g}$ was observed in non-sterile soil spiked with $10 \%$ of tank bottom sludge. Low bacterial numbers may be because of the use of sandy soil with low nutrients and microflora. An increase in bacterial population was encountered in all amended soil samples particularly with rhamnolipid solution (Table 2). This may be due to the biosurfactant induced desorption of hydrocarbons from soil to the aqueous phase of soil slurries leading to increased microbial mineralization, either by increasing hydrocarbon solubility or by increasing the contact surface with hydrophobic compounds (Moran et al., 2000). Two orders of magnitude increase 
in the bacterial population were observed in soil samples spiked with $10 \%$ petroleum TBS after 56 days of incubation. The available nutrients were rapidly assimilated by soil microbes, thus depleting the nutrient reserves. So the objective of augmenting NPK solution to the soil

samples was to restore the availability of essential nutrients. Several researchers have recently described an increase in microbial activity and rate of biodegradation following addition of inorganic nutrients (Radwan et al., 2000; Del 'Arco and de Franca, 2001; Vasudevan and Rajaram, 2001).

\subsection{Change in protein concentration during degradation}

The protein estimation by Bradford's method was effective in monitoring the microbial population in the hydrocarbon contaminated soil sample. In non-sterile control the initial concentration of protein observed was $1.25 \pm 0.16 \mathrm{mg} / \mathrm{g}$ of soil, whereas in sterile soil it was $0.001 \pm 0.0 \mathrm{mg} / \mathrm{g}$. This reduction may be due to the denaturation of proteins present in the soil during sterilization. The various amendments and mixed consortium caused proliferation of bacteria up to 56 days of incubation and resulted in an increased protein content in these treatments up to a value of $6.24 \mathrm{mg} / \mathrm{g}$ in soil samples spiked with 10\% TBS (Table 3).

\subsection{Biodegradation vs Surface tension}

The indigenous microbial community of non-sterile and sterile soil caused a slight decrease in surface tension, evidencing that those microorganisms on their own were not able to produce a significant amounts of biosurfactants. Surface tension of the soil extract was $69.7 \pm 0.4-71.1 \pm 0.6 \mathrm{mN} / \mathrm{m}$ (milli-Newton/meter), which was reduced to $52.3 \pm 2.2$ and $48.1 \pm 1.8 \mathrm{mN} / \mathrm{m}$ in NS+TBS+RL and SS+TBS+RL amended with 10\% TBS respectively. A reduction in surface tension occurred because of the presence of rhamnolipid (RL) in 
NS+TBS+RL and SS+TBS+RL with 20\% TBS amendment (Table 4). Furthermore, in soil samples augmented with a bacterial consortium and amended with rhamnolipid and NPK a significant reduction in surface tension was noted after 56 days of incubation. A possible reason for this may be the rhamnolipid mediated desorption of petroleum hydrocarbons, which increased their solubility and hence the biological activity of indigenous microflora or added hydrocarbon degrading bacterial consortium. In a study by Oberbremer and MullerHurtig (1989), a positive correlation has been obtained between reduction in surface tension of the fluid phase in a stirred soil bioreactor and the onset of biodegradation of hydrophobic petroleum hydrocarbons. It has also been previously reported about the rhamnolipid biosurfactant mediated reduction in surface tension (Banat et al., 2000; Noordman et al., 2000).

\subsection{Effect of degradation on $\mathrm{pH}$}

$\mathrm{pH} 7.2 \pm 0.3$ to $7.2 \pm 0.4$ was estimated in the sterile and non-sterile soil samples. Alternatively, in soil samples amended with mixed consortium, rhamnolipid or NPK, an increase in pH was observed after 56 days of incubation suggesting the release of by-products during hydrocarbon degradation (Table 5).

\subsection{Biodegradation of n-alkanes}

Gas chromatographic analyses revealed all hexane soluble n-alkanes in the range of nC8nC40, which were relatively abundant in tank bottom crude oil sludge. The degradation of the above was discussed in four different ranges such as nC8-nC11, nC12-nC21, nC22-nC31 and nC32-nC40. The nC8-nC11 range consisted of volatile hydrocarbons. Percentage of hydrocarbon degradation of about 100\% (nC8-nC11), 83-98\% (nC12-nC21), 80-85\% (nC22- 
nC31) and 57-73\% (nC32-nC40) was noted in non-sterile soil samples with 10\% TBS amended with RL+NPK+BC (Fig 1). Among the different treatments, in $\mathrm{NS}+\mathrm{TBS}+\mathrm{RL}+\mathrm{NPK}+\mathrm{BC}$ spiked with $10 \%$ TBS all the hydrocarbons in the range of nC8nC11 were degraded. Whereas, in SS+TBS+RL+NPK+BC with $10 \%$ TBS, NS+TBS+RL+NPK+BC and SS+TBS+RL+NPK+BC with $20 \%$ TBS only $81-87 \%, 64-83 \%$ and 55-61\% degradation was observed, respectively (Fig 4, 5, 6).

The slowing tendency of utilization after 56 days of incubation observed with soil samples amended with $10 \%$ TBS was not only due to the substrate depletion but also to the fact that the remaining hydrocarbons were relatively more resistant to biodegradation. The rate of petroleum biodegradation and quantity of hydrocarbon degraded depend on environmental conditions, chemical structure of the pollutant compounds, type and amount of oil present at the contaminated site (Del 'Arco and de Franca, 2001). At 20\% TBS concentration, the decrease in microbial degradation activity may be due to the toxicity caused by higher hydrocarbon contamination (Fig 2).

The bacterial consortium enhanced the degradation of all the fractions of hydrocarbons from nC8-nC40 to various degrees in sterile and non-sterile samples supplemented with 10\% and $20 \%$ TBS. This observation is in general agreement with literature regarding the use of bioaugmentation (Mulligan et al., 2001). When compared to all the sets, different treatments of non-sterile soil (NS+TBS, NS+TBS+RL, NS+TBS+NPK, NS+TBS+BC and NS+TBS+RL+NPK+BC) spiked with 10\% TBS exhibited higher percentage of hydrocarbon degradation (Fig 3). The degree of degradation observed with SS+TBS was lower than that in the NS+TBS. These results indicated the ubiquitous distribution of diversified hydrocarbon structures, originating in particular from plants in the environment and consequently the presence of bacterial degraders for them. Furthermore, the TBS spiked soil samples treated 
with rhamnolipid or NPK lost substantially fewer hydrocarbons in the range of nC12-nC40 than those treated with bacterial consortium. In our study, no lag period was observed preceding petroleum hydrocarbon mineralisation in sterile soil samples spiked with TBS, suggesting the presence of an active hydrocarbon degrading population in the TBS. Addition of NPK solution alone had only a minor effect on hydrocarbon degradation compared to other soil amendments which may be due to a slight increase in biological activity of the microflorae present in soil and sludge. The addition of rhamnolipid however, significantly enhanced the rate of biodegradation of hydrocarbon fractions by the bacterial consortium and the NPK solution in all the treatments.

When hydrocarbons are present in non-inhibitory concentration (available or desorbed form) in the soil it may affect the rate of biodegradation by enhancing the biodegradation activity of the indigenous microbial population. Adding surfactants to soil contaminated with hydrophobic contaminants may increase the bioavailability of these compounds to hydrocarbon degrading microorganisms (Banat et al., 1991; Banat, 1995). Our results revealed complete degradation of nC8-nC11 and 73-98\% of nC12 - nC40 with designed bacterial consortium amended with rhamnolipid and NPK solution in 10\% TBS spiked soil samples at 56 days of incubation (Fig 3 and Fig 5), which was comparatively higher than all the earlier reports.

Dave et al. (1994) achieved a 70\% bioremediation of a slop oil contaminated soil using oil degrading cultures. One of the main reasons for the prolonged persistence of hydrophobic hydrocarbons in contaminated environments is their strong adsorption even on coarse-grained and organic free soils by microporosity, so that they are no longer available for hydrocarbon degrading microorganisms and remain even after bioremediation. Hence for efficient and complete biodegradation, solubilization of these hydrocarbons with biosurfactants prior to 
bioaugmentation is advantageous. Moreover, use of biosurfactant producing hydrocarbon degrading microorganisms for bioaugmentation to enhance hydrocarbon degradation offer the advantage of a continuous supply of a non-toxic and biodegradable surfactant at a low cost (Moran et al., 2000). However, the potential benefits of insitu application of surfactants must also be weighed against the possibility of increased ground water contamination caused by surfactant mediated enhanced mobility. Hence, the use of a repeated but smaller dosage schedule should be investigated as a means to control contaminant mobility together with careful monitoring of the rate and extent of hydrocarbon degradation.

All the results were statistically analyzed using ANOVA and DMRT procedures to determine significant parameters. The results presented in Table 6 revealed that all the above parameters were highly influenced by single factors (concentration (C), amendments (A), number of days (D) treated); two factor combinations ( $\mathrm{C} \times \mathrm{A}, \mathrm{C} \times \mathrm{D}$ and $\mathrm{A} \times \mathrm{D}$ ) and three factor combinations (C x A x D) at 1\% probability level. However, the number of days treated (D), and the two factor combination $\mathrm{C} \times \mathrm{A}$ for surface tension and $\mathrm{pH}$ were significant at $5 \%$ probability level. Moreover, the two factor combinations C x D and A x D and the three factor combination $\mathrm{C} \times \mathrm{A} \times \mathrm{D}$ were not significant at $1 \%$ or $5 \%$ probability levels for surface tension and $\mathrm{pH}$.

\section{Conclusion}

Several strategies have been attempted to boost the bioremediation of hydrocarbon polluted sites. We found that bioaugmentation with designed bacterial consortium followed by addition of rhamnolipid biosurfactant and NPK solution to soils contaminated with $10 \%$ tank bottom sludge enhanced the rate of biodegradation over a period of 56 days. Pre-treatment of hydrocarbon contaminated soil with biosurfactants enhanced bioavailability of the 
hydrocarbons to microbial population. Furthermore, supplementation with inorganic nutrients like NPK solution enhanced the secondary successions of crude petroleum utilizers. For bioremediation, a single inoculation with the biosufactant producing hydrocarbon degrading bacterial consortium at the beginning of the process would reduce the cost of inoculum preparation considerably. Hence we suggest the above combined treatment as a possible bioremediation technology for reclamation of oil sludge polluted soils. Statistical analyses using ANOVA and DMRT also showed that concentration, amendment and days of treatment at different factorial designs (C, A, D, C x A, C x D, A x D and C x A x D) were significant at $1 \%$ probability level for bacterial growth and protein concentration. Hence bioremediation of n-alkanes in $10 \%$ sludge amended soil can be achieved by treating with BC, NPK and rhamnolipid BS for 56 days.

\section{Acknowledgements}

We wish to thank the Environment and Heritage Service, DOE for FRDF financial support under the Northern Ireland Single Programme (Ref. WM47/99) and Mr. Tommy Millar, School of Biomedical Sciences, University of Ulster for his technical assistance in Gas Chromatographic analyses.

\section{References}

Banat, I.M., Samarah, N., Murad, M., Horne, R., Banerjee, S., 1991. Biosurfactant production and use in oil tank clean-up. World J. Microbiol. Biotechnol. 7, 80-84.

Banat, I.M., 1995. Biosurfactants production and possible uses in microbial enhanced oil recovery and oil pollution remediation: a review. Bioresource Technol. 51,1-12. 
Banat, I.M., Makkar, R.S., Cameotra, S.S., 2000. Potential commercial applications of microbial surfactants. Appl. Microbiol. Biotechnol. 53, 495-508.

Bradford, M.M., 1976. A rapid and sensitive method for the quantification of microgram quantities of protien utilizing the principle of protein-dye binding. Anal. Biochem. 72, 248-254.

Dave, H., Ramakrishna, C., Bhatt, B.D., Desai, J.D., 1994. Biodegradation of slope oil from petroleum Industry and bioreclamation of slop oil contaminated soil. World J. Microbiol. Biotechnol. 10, 653-656.

Del ‘Arco, J.P., de Franca, F.P., 2001. Influence of oil contamination levels on hydrocarbon biodegradation in sandy sediments. Environ. Pollut. 110, 515-519.

Ferrari, M.D., Neirotti, E., Albornoz, C., Mostazo, M.R., Cozzo, M., 1996. Biotreatment of hydrocarbons from petroleum tank bottom sludges in soil slurries. Biotechnol. Lett. 18, 12411246.

Gomez, K.A., Gomez, A. A. (Eds.) 1984. Statistical procedure for agricultural research. John Wiley and Sons, New York. pp. 680.

Moran, A.C., Olivera, N., Commendatore, M., Esteves, J.L., Sineriz, F., 2000. Enhancement of hydrocarbon waste biodegardation by addition of a biosurfactant from Bacillus subtilis O9. Biodegradation. 11, 65-71.

Mulligan, C.N., Yong, R.N., and Gibbs, B.F., 2001. Surfactant enhanced remediation of contaminated soil: a review. Eng. Geol. 60, 371-380.

Noordman, W.H., Brusseau, M.L., and Janssen, D.B., 2000. Adsorption of a multicomponent rhamnolipid surfactant to soil. Environ. Sci. Technol. 34, 832-838. 
Oberbremer, A., Muller-Hurtig, R., 1989. Aerobic stepwise hydrocarbon degradation and formation of biosurfactants by an original soil population in a stirred reactor. Appl. Microbiol. Biotechnol. 31, 582-586.

Radwan, S.S., Al-Mailem, D., El-Nemr, I., Salamah, S., 2000. Enhanced remediation of hydrocarbon contaminated desert soil fertilized with organic carbons. Int. Biodeterior. Biodegrad. 46, 129-132.

Rahman, K.S.M., Banat, I.M., Thahira-Rahman, J., Thayumanavan, T., Lakshmanaperumalsamy, P., 2002a. Bioremediation of Gasoline contaminated soil by bacterial consortium amended with poultry litter, coir-pith and rhamnolipid biosurfactant. Bioresource Technol. 81, 25-32.

Rahman, K.S.M., Thahira-Rahman, J., Lakshmanaperumalsamy, P., Banat, I.M., 2002b. Occurrence of crude oil degrading bacteria in gasoline and diesel station soils. J. Basic Microbiol. 42, 286-293.

Vasudevan, N., Rajaram, P., 2001. Bioremediation of oil sludge- contaminated soil. Environ. Int. 26, 409-411. 
Table 1. Preparation of the different treatments of sterile and non-sterile soil samples

\begin{tabular}{|c|c|c|c|c|c|c|}
\hline Amendments & $\begin{array}{l}\text { NS / SS } \\
\text { (g) }\end{array}$ & $\begin{array}{l}\text { TBS } \\
(\%)\end{array}$ & $\begin{array}{l}\mathrm{RL} \\
(\mathrm{mg})\end{array}$ & $\begin{array}{l}\text { NPK } \\
\text { (mg) }\end{array}$ & $\begin{array}{l}\mathrm{BC} \\
(\mathrm{ml})\end{array}$ & $\begin{array}{l}\text { Moisture } \\
\text { content } \\
(\%)\end{array}$ \\
\hline $\mathrm{NS}+\mathrm{TBS}$ & 100 & 10 or 20 & & & & 1.2 \\
\hline $\mathrm{NS}+\mathrm{TBS}+\mathrm{RL}$ & 100 & 10 or 20 & 4 & & & 1.2 \\
\hline $\mathrm{NS}+\mathrm{TBS}+\mathrm{NPK}$ & 100 & 10 or 20 & & 0.1 & & 1.2 \\
\hline $\mathrm{NS}+\mathrm{TBS}+\mathrm{BC}$ & 100 & 10 or 20 & & & 1 & 1.2 \\
\hline $\mathrm{NS}+\mathrm{TBS}+\mathrm{RL}+\mathrm{NPK}+\mathrm{BC}$ & 100 & 10 or 20 & 4 & 0.1 & 1 & 1.2 \\
\hline $\mathrm{SS}+\mathrm{TBS}$ & 100 & 10 or 20 & & & & 1.2 \\
\hline $\mathrm{SS}+\mathrm{TBS}+\mathrm{RL}$ & 100 & 10 or 20 & 4 & & & 1.2 \\
\hline $\mathrm{SS}+\mathrm{TBS}+\mathrm{NPK}$ & 100 & 10 or 20 & & 0.1 & & 1.2 \\
\hline $\mathrm{SS}+\mathrm{TBS}+\mathrm{BC}$ & 100 & 10 or 20 & & & 1 & 1.2 \\
\hline $\mathrm{SS}+\mathrm{TBS}+\mathrm{RL}+\mathrm{NPK}+\mathrm{BC}$ & 100 & 10 or 20 & 4 & 0.1 & 1 & 1.2 \\
\hline
\end{tabular}

NS - Non-sterile soil ; SS - Sterile soil; TBS - Tank Bottom Sludge; BC - Bacterial Consortium;

RL - Rhamnolipid; NPK - Nitrogen, Phosphorus and Potassium solution. 
Table 2. Bacterial growth during degradation of n-Alkane in oil sludge treated with different amendments

\begin{tabular}{|c|c|c|c|c|c|c|c|c|c|}
\hline \multirow{3}{*}{ S.No } & \multirow{3}{*}{$\begin{array}{l}\text { Amendments / } \\
\text { Days }\end{array}$} & \multicolumn{8}{|c|}{ Bacteria (CFU/g) } \\
\hline & & \multicolumn{4}{|l|}{$10 \%$ sludge } & \multicolumn{4}{|l|}{$20 \%$ sludge } \\
\hline & & 0 & 28 & 56 & 84 & 0 & 28 & 56 & 84 \\
\hline 1 & NS+TBS & $\begin{array}{l}2.1 \pm 0.7^{\mathrm{B}} \\
\times 10^{3} \mathrm{e}^{\mathrm{A}}\end{array}$ & $\begin{array}{l}6.1 \pm 0.3 \\
x 10^{3} \mathrm{e}\end{array}$ & $\begin{array}{l}7.2 \pm 0.2 \\
\mathrm{x} 10^{3} \mathrm{e}\end{array}$ & $\begin{array}{l}2.4 \pm 0.4 \\
\times 10^{3} \mathrm{e}\end{array}$ & $\begin{array}{l}2.7 \pm 0.3 \\
x 10^{3} \mathrm{e}\end{array}$ & $\begin{array}{l}4.1 \pm 0.2 \\
\times 10^{3} \mathrm{e}\end{array}$ & $\begin{array}{l}7.3 \pm 0.6 \\
\times 10^{3} \mathrm{e}\end{array}$ & $\begin{array}{l}6.7 \pm 0.6 \\
\times 10^{3} \mathrm{e}\end{array}$ \\
\hline 2 & $\mathrm{NS}+\mathrm{TBS}+\mathrm{RL}$ & $\begin{array}{l}7.9 \pm 0.9 \\
\times 10^{3} \mathrm{C}\end{array}$ & $\begin{array}{l}8.1 \pm 0.5 \\
\times 10^{3} \mathrm{~d}\end{array}$ & $\begin{array}{l}89.0 \pm 2.3 \\
x 10^{3} \mathrm{~d}\end{array}$ & $\begin{array}{l}59.0 \pm 1.2 \\
\times 10^{3} \mathrm{~d}\end{array}$ & $\begin{array}{l}92.0 \pm 4.9 \\
\times 10^{3} \mathrm{C}\end{array}$ & $\begin{array}{l}31.0 \pm 1.8 \\
x 10^{3} \mathrm{~d}\end{array}$ & $\begin{array}{l}56.0 \pm 4.1 \\
x 10^{3} \mathrm{~d}\end{array}$ & $\begin{array}{l}39.0 \pm 0.1 \\
\times 10^{3} \mathrm{~d}\end{array}$ \\
\hline 3 & $\mathrm{NS}+\mathrm{TBS}+\mathrm{NPK}$ & $\begin{array}{l}2.8 \pm 0.4 \\
\times 10^{3} \mathrm{~d}\end{array}$ & $\begin{array}{l}39.0 \pm 1.1 \\
\times 10^{3} \mathrm{C}\end{array}$ & $\begin{array}{l}660.0 \pm 15 \\
\times 10^{3} \mathrm{C}\end{array}$ & $\begin{array}{l}440.0 \pm 16 \\
\times 10^{3} \mathrm{C}\end{array}$ & $\begin{array}{l}6.4 \pm 2.3 \\
\times 10^{3} \mathrm{~d}\end{array}$ & $\begin{array}{l}43.0 \pm 2.6 \\
\times 10^{3} \mathrm{c}\end{array}$ & $\begin{array}{l}91.0 \pm 6.3 \\
\times 10^{3} \mathrm{C}\end{array}$ & $\begin{array}{l}63.0 \pm 2.5 \\
\times 10^{3} \mathrm{c}\end{array}$ \\
\hline 4 & $\mathrm{NS}+\mathrm{TBS}+\mathrm{BC}$ & $\begin{array}{l}240.0 \pm 11 \\
\mathrm{x} 10^{3} \mathrm{~b}\end{array}$ & $\begin{array}{l}1.8 \pm 0.2 \\
\mathrm{x} 10^{7} \mathrm{~b}\end{array}$ & $\begin{array}{l}4.3 \pm 0.1 \\
\times 10^{8} \mathrm{a}\end{array}$ & $\begin{array}{l}3.8 \pm 0.5 \\
\times 10^{8} \mathrm{~b}\end{array}$ & $\begin{array}{l}220.0 \pm 16 \\
\times 10^{3} \mathrm{~b}\end{array}$ & $\begin{array}{l}3.8 \pm 0.1 \\
\times 10^{6} \mathrm{~b}\end{array}$ & $\begin{array}{l}5.6 \pm 0.2 \\
\mathrm{x} 10^{7} \mathrm{~b}\end{array}$ & $\begin{array}{l}2.8 \pm 0.3 \\
\times 10^{7} \mathrm{~b}\end{array}$ \\
\hline 5 & $\begin{array}{l}\mathrm{NS}+\mathrm{TBS}+\mathrm{RL}+ \\
\mathrm{NPK}+\mathrm{BC}\end{array}$ & $\begin{array}{l}810.0 \pm 17 \\
\times 10^{3} \mathrm{a}\end{array}$ & $\begin{array}{l}6.8 \pm 0.4 \\
\times 10^{8} \mathrm{a} \\
\end{array}$ & $\begin{array}{l}3.8 \pm 0.3 \\
\times 10^{8} \mathrm{~b} \\
\end{array}$ & $\begin{array}{l}4.1 \pm 0.5 \\
\times 10^{10} \mathrm{a} \\
\end{array}$ & $\begin{array}{l}500.0 \pm 37 \\
\times 10^{3} \mathrm{a}\end{array}$ & $\begin{array}{l}1.7 \pm 0.1 \\
\times 10^{7} \mathrm{a} \\
\end{array}$ & $\begin{array}{l}2.6 \pm 0.2 \\
\times 10^{8} \mathrm{a} \\
\end{array}$ & $\begin{array}{l}2.1 \pm 0.1 \\
\times 10^{8} \mathrm{a} \\
\end{array}$ \\
\hline 6 & SS+TBS & $\begin{array}{l}0.12 \pm 0.01 \\
\times 10^{3} \mathrm{e}\end{array}$ & $\begin{array}{l}0.80 \pm 0.07 \\
\times 10^{3} \mathrm{C}\end{array}$ & $\begin{array}{l}0.97 \pm 0.8 \\
\times 10^{3} \mathrm{e}\end{array}$ & $\begin{array}{l}0.27 \pm 0.04 \\
\times 10^{3} \mathrm{e}\end{array}$ & $\begin{array}{l}0.14 \pm 0.02 \\
\times 10^{3} \mathrm{e}\end{array}$ & $\begin{array}{l}0.37 \pm 0.02 \\
\times 10^{3} \mathrm{~d}\end{array}$ & $\begin{array}{l}0.68 \pm 0.04 \\
\times 10^{3} \mathrm{~d}\end{array}$ & $\begin{array}{l}0.51 \pm 0.04 \\
\times 10^{3} \mathrm{C}\end{array}$ \\
\hline 7 & $\mathrm{SS}+\mathrm{TBS}+\mathrm{RL}$ & $\begin{array}{l}0.18 \pm 0.01 \\
\times 10^{3} \mathrm{C}\end{array}$ & $\begin{array}{l}0.28 \pm 0.01 \\
\mathrm{x} 10^{3} \mathrm{e}\end{array}$ & $\begin{array}{l}2.50 \pm 0.3 \\
\times 10^{3} \mathrm{~d}\end{array}$ & $\begin{array}{l}1.10 \pm 0.04 \\
\times 10^{3} \mathrm{~d}\end{array}$ & $\begin{array}{l}0.19 \pm 0.01 \\
\times 10^{3} \mathrm{~d}\end{array}$ & $\begin{array}{l}0.27 \pm 0.01 \\
\times 10^{3} \mathrm{e}\end{array}$ & $\begin{array}{l}0.99 \pm 0.01 \\
\times 10^{3} \mathrm{C}\end{array}$ & $\begin{array}{l}0.42 \pm 0.03 \\
\times 10^{3} \mathrm{~d}\end{array}$ \\
\hline 8 & SS+TBS+NPK & $\begin{array}{l}0.16 \pm 0.02 \\
\times 10^{3} \mathrm{~d}\end{array}$ & $\begin{array}{l}0.56 \pm 0.04 \\
\times 10^{3} \mathrm{~d}\end{array}$ & $\begin{array}{l}6.4 \pm 0.5 \\
\times 10^{3} \mathrm{C}\end{array}$ & $\begin{array}{l}5.2 \pm 0.6 \\
\times 10^{3} \mathrm{C}\end{array}$ & $\begin{array}{l}0.22 \pm 0.02 \\
\times 10^{3} \mathrm{C}\end{array}$ & $\begin{array}{l}0.84 \pm 0.08 \\
\times 10^{3} \mathrm{C}\end{array}$ & $\begin{array}{l}0.32 \pm 0.02 \\
\times 10^{3} \mathrm{e}\end{array}$ & $\begin{array}{l}0.12 \pm 0.01 \\
\times 10^{3} \mathrm{e}\end{array}$ \\
\hline 9 & $\mathrm{SS}+\mathrm{TBS}+\mathrm{BC}$ & $\begin{array}{l}210.0 \pm 1.3 \\
\times 10^{3} \mathrm{~b}\end{array}$ & $\begin{array}{l}640.0 \pm 49 \\
\times 10^{3} \mathrm{~b}\end{array}$ & $\begin{array}{l}290.0 \pm 19 \\
\times 10^{3} \mathrm{~b}\end{array}$ & $\begin{array}{l}170.0 \pm 14 \\
\times 10^{3} \mathrm{~b}\end{array}$ & $\begin{array}{l}18.0 \pm 0.1 \\
\times 10^{3} \mathrm{~b}\end{array}$ & $\begin{array}{l}6.7 \pm 0.04 x \\
10^{6} b\end{array}$ & $\begin{array}{l}9.1 \pm 0.9 \\
\times 10^{6} \mathrm{~b}\end{array}$ & $\begin{array}{l}8.9 \pm 0.7 \\
\times 10^{6} \mathrm{~b}\end{array}$ \\
\hline 10 & $\begin{array}{l}\mathrm{SS}+\mathrm{TBS}+\mathrm{RL}+ \\
\mathrm{NPK}+\mathrm{BC}\end{array}$ & $\begin{array}{l}370.0 \pm 55 \\
\times 10^{3} \mathrm{a}\end{array}$ & $\begin{array}{l}9.1 \pm 0.7 \\
\times 10^{6} \mathrm{a} \\
\end{array}$ & $\begin{array}{l}3 \pm 0.1 \\
\times 10^{7} \mathrm{a} \\
\end{array}$ & $\begin{array}{l}2.7 \pm 0.1 \\
\times 10^{7} \mathrm{a}\end{array}$ & $\begin{array}{l}270.0 \pm 16 \\
\times 10^{3} \mathrm{a}\end{array}$ & $\begin{array}{l}4.6 \pm 0.02 \times \\
10^{7} \mathrm{a}\end{array}$ & $\begin{array}{l}3.9 \pm 0.2 \\
\times 10^{8} \mathrm{a}\end{array}$ & $\begin{array}{l}1.9 \pm 0.01 x \\
10^{8} \mathrm{a}\end{array}$ \\
\hline
\end{tabular}

NS - Non sterile soil; SS - Sterile soil; TBS - Tank bottom sludge; BC - Bacterial consortium; NPK - Nitrogen, Phosphorus,

Potassium solution; RL - Rhamnolipid biosurfactant solution

A a, b, c, d, e: Arithmetic means with the same letter are not significantly different from each other at 5\% probability level by Duncan’s

Multiple Range Test (DMRT); ${ }^{\mathrm{B}}$ Standard Error. 
Table 3. Protein concentration during degradation of $\mathbf{n}$-Alkane in oil sludge treated with different amendments for a period of up to 84 days.

\begin{tabular}{|c|c|c|c|c|c|c|c|c|c|}
\hline \multirow{3}{*}{ S.No } & \multirow{3}{*}{$\begin{array}{l}\text { Amendments / } \\
\text { Days }\end{array}$} & \multicolumn{8}{|c|}{ Protein $(\mathrm{mg} / \mathrm{g})$} \\
\hline & & \multicolumn{4}{|l|}{$10 \%$ sludge } & \multicolumn{4}{|l|}{$20 \%$ sludge } \\
\hline & & 0 & 28 & 56 & 84 & 0 & 28 & 56 & 84 \\
\hline 1 & NS+TBS & $1.2 \mathrm{e}^{\mathrm{A}} \pm 0.16^{\mathrm{B}}$ & $1.72 \mathrm{~d} \pm 0.15$ & $2.19 d \pm 0.13$ & $2.23 d \pm 0.29$ & $0.08 d \pm 0.00$ & $1.12 \mathrm{e} \pm 0.09$ & $1.97 e \pm 0.11$ & $2.10 \mathrm{e} \pm 0.17$ \\
\hline 2 & $\mathrm{NS}+\mathrm{TBS}+\mathrm{RL}$ & $1.74 \mathrm{c} \pm 0.11$ & $2.07 c \pm 0.08$ & $2.56 c \pm 0.24$ & $2.58 c \pm 0.17$ & $1.20 c \pm 0.02$ & $1.88 c \pm 0.06$ & $2.12 \mathrm{~d} \pm 0.17$ & $2.32 \mathrm{~d} \pm 0.21$ \\
\hline 3 & $\mathrm{NS}+\mathrm{TBS}+\mathrm{NPK}$ & $1.29 \mathrm{~d} \pm 0.07$ & $1.58 \mathrm{e} \pm 0.04$ & $1.58 \mathrm{e} \pm 0.08$ & $2.25 d \pm 0.09$ & $0.08 d \pm 0.01$ & $1.24 \mathrm{~d} \pm 0.10$ & $2.30 c \pm 0.20$ & $2.40 \mathrm{c} \pm 0.28$ \\
\hline 4 & $\mathrm{NS}+\mathrm{TBS}+\mathrm{BC}$ & $2.15 b \pm 0.19$ & $3.99 b \pm 0.24$ & $4.24 b \pm 0.21$ & $4.83 b \pm 0.16$ & $1.70 \mathrm{~b} \pm 0.11$ & $3.10 b \pm 0.17$ & $3.70 b \pm 0.24$ & $3.98 b \pm 0.11$ \\
\hline 5 & $\begin{array}{l}\mathrm{NS}+\mathrm{TBS}+\mathrm{RL}+ \\
\mathrm{NPK}+\mathrm{BC}\end{array}$ & $2.41 \mathrm{a} \pm 0.21$ & $4.93 a \pm 0.21$ & $6.24 a \pm 0.16$ & $6.00 \mathrm{a} \pm 0.37$ & $2.01 \mathrm{a} \pm 0.15$ & $3.50 \mathrm{a} \pm 0.29$ & $4.12 \mathrm{a} \pm 0.55$ & $4.51 \mathrm{a} \pm 0.24$ \\
\hline 6 & SS+TBS & $0.01 d \pm 0.00$ & $0.05 d \pm 0.01$ & $0.07 c \pm 0.00$ & $0.08 c \pm 0.00$ & $0.02 c \pm 0.00$ & $0.06 c \pm 0.00$ & $0.09 c \pm 0.01$ & $0.09 c \pm 0.01$ \\
\hline 7 & $\mathrm{SS}+\mathrm{TBS}+\mathrm{RL}$ & $0.01 \mathrm{~d} \pm 0.00$ & $0.05 d \pm 0.00$ & $0.07 c \pm 0.00$ & $0.09 c \pm 0.01$ & $0.02 c \pm 0.00$ & $0.06 c \pm 0.00$ & $0.07 c \pm 0.00$ & $0.08 c \pm 0.00$ \\
\hline 8 & $\mathrm{SS}+\mathrm{TBS}+\mathrm{NPK}$ & $0.02 \mathrm{c} \pm 0.00$ & $0.06 c \pm 0.00$ & $0.07 c \pm 0.00$ & $0.07 c \pm 0.00$ & $0.03 c \pm 0.00$ & $0.05 c \pm 0.00$ & $0.06 c \pm 0.00$ & $0.07 c \pm 0.00$ \\
\hline 9 & $\mathrm{SS}+\mathrm{TBS}+\mathrm{BC}$ & $1.87 \mathrm{~b} \pm 0.06$ & $3.20 b \pm 0.24$ & $3.50 b \pm 0.27$ & $3.59 b \pm 0.27$ & $1.70 b \pm 0.08$ & $2.70 b \pm 0.15$ & $3.05 b \pm 0.09$ & $3.21 b \pm 0.24$ \\
\hline 10 & $\begin{array}{l}\mathrm{SS}+\mathrm{TBS}+\mathrm{RL}+ \\
\mathrm{NPK}+\mathrm{BC}\end{array}$ & $2.73 a \pm 0.18$ & $3.98 a \pm 0.18$ & $4.12 \mathrm{a} \pm 0.39$ & $4.37 a \pm 0.46$ & $2.91 \mathrm{a} \pm 0.24$ & $3.52 \mathrm{a} \pm 0.30$ & $3.98 a \pm 0.27$ & $4.10 \mathrm{a} \pm 0.35$ \\
\hline
\end{tabular}

NS - Non sterile soil; SS - Sterile soil; TBS - Tank bottom sludge; BC - Bacterial consortium; NPK - Nitrogen, Phosphorus,

Potassium solution; RL - Rhamnolipid biosurfactant solution

A a, b, c, d, e: Arithmetic means with the same letter are not significantly different from each other at 5\% probability level by Duncan's

Multiple Range Test (DMRT)

${ }^{B}$ Standard Error. 
Table 4. Surface tension of samples during degradation of n-Alkane in oil sludge treated with different amendments for a period of up to 84 days.

\begin{tabular}{|c|c|c|c|c|c|c|c|c|c|}
\hline \multirow{3}{*}{ S.No } & \multirow{3}{*}{$\begin{array}{l}\text { Amendments / } \\
\text { Days }\end{array}$} & \multicolumn{8}{|c|}{ Surface tension (mN/m) } \\
\hline & & \multicolumn{4}{|l|}{$10 \%$ sludge } & \multicolumn{4}{|l|}{$20 \%$ sludge } \\
\hline & & 0 & 28 & 56 & 84 & 0 & 28 & 56 & 84 \\
\hline 1 & $\mathrm{NS}+\mathrm{TBS}$ & $69.7 c^{A} \pm 0.4^{B}$ & $70.3 a \pm 0.9$ & $65.5 b \pm 2.7$ & $67.7 b \pm 0.9$ & $70.1 b \pm 0.5$ & $67.1 b \pm 0.4$ & $63.1 c \pm 1.9$ & $70.5 a \pm 0.4$ \\
\hline 2 & $\mathrm{NS}+\mathrm{TBS}+\mathrm{RL}$ & $52.3 d \pm 2.2$ & $69.8 \mathrm{~b} \pm 0.4$ & $69.7 \mathrm{a} \pm 3.1$ & $65.1 \mathrm{c} \pm 1.1$ & $57.1 c \pm 2.1$ & $69.1 \mathrm{a} \pm 0.2$ & $66.8 \mathrm{a} \pm 0.3$ & $69.9 \mathrm{~b} \pm 1.0$ \\
\hline 3 & $\mathrm{NS}+\mathrm{TBS}+\mathrm{NPK}$ & $71.5 a \pm 0.4$ & $66.7 d \pm 1.4$ & $62.9 \mathrm{~d} \pm 1.2$ & $62.9 \mathrm{~d} \pm 0.4$ & $70.2 b \pm 0.1$ & $61.8 \mathrm{e} \pm 1.1$ & $59.8 \mathrm{e} \pm 0.5$ & $67.4 \mathrm{e} \pm 1.4$ \\
\hline 4 & $\mathrm{NS}+\mathrm{TBS}+\mathrm{BC}$ & $70.5 b \pm 0.5$ & $68.8 c \pm 1.4$ & $63.3 c \pm 2.1$ & $69.7 a \pm 0.3$ & $70.5 a \pm 0.4$ & $65.1 c \pm 2.3$ & $63.3 b \pm 0.7$ & $69.5 c \pm 0.4$ \\
\hline 5 & $\begin{array}{l}\mathrm{NS}+\mathrm{TBS}+\mathrm{RL}+ \\
\mathrm{NPK}+\mathrm{BC}\end{array}$ & $32.1 \mathrm{e} \pm 1.6$ & $62.7 \mathrm{e} \pm 2.9$ & $57.2 \mathrm{e} \pm 3.0$ & $61.5 \mathrm{e} \pm 1.1$ & $41.2 \mathrm{~d} \pm 2.1$ & $63.1 d \pm 2.4$ & $61.1 d \pm 1.2$ & $68.1 d \pm 2.3$ \\
\hline 6 & $\mathrm{SS}+\mathrm{TBS}$ & $70.1 b \pm 1.5$ & $70.6 \mathrm{a} \pm 0.2$ & $69.4 \mathrm{a} \pm 0.6$ & $69.2 \mathrm{a} \pm 0.9$ & $71.1 b \pm 0.6$ & $69.2 \mathrm{a} \pm 1.3$ & $68.9 a \pm 2.0$ & $67.5 b \pm 0.7$ \\
\hline 7 & $\mathrm{SS}+\mathrm{TBS}+\mathrm{RL}$ & $48.1 d \pm 1.8$ & $61.1 c \pm 3.1$ & $62.9 b \pm 2.4$ & $57.4 e \pm 2.3$ & $67.1 \mathrm{~d} \pm 1.2$ & $64.5 \mathrm{e} \pm 3.4$ & $64.7 d \pm 3.4$ & $65.5 d \pm 1.5$ \\
\hline 8 & $\mathrm{SS}+\mathrm{TBS}+\mathrm{NPK}$ & $69.4 c \pm 0.1$ & $69.9 b \pm 1.2$ & $61.7 c \pm 1.5$ & $67.9 b \pm 1.7$ & $70.1 c \pm 0.2$ & $67.8 b \pm 2.9$ & $66.9 b \pm 1.6$ & $66.9 c \pm 3.4$ \\
\hline 9 & $\mathrm{SS}+\mathrm{TBS}+\mathrm{BC}$ & $71.7 a \pm 0.4$ & $70.4 a \pm 0.6$ & $62.9 b \pm 3.1$ & $64.1 c \pm 2.0$ & $71.5 a \pm 0.5$ & $64.9 d \pm 3.1$ & $66.5 c \pm 3.3$ & $67.6 a \pm 2.9$ \\
\hline 10 & $\begin{array}{l}\mathrm{SS}+\mathrm{TBS}+\mathrm{RL}+ \\
\mathrm{NPK}+\mathrm{BC}\end{array}$ & $40.1 \mathrm{e} \pm 2.6$ & $59.3 d \pm 1.7$ & $61.9 c \pm 0.4$ & $62.4 d \pm 1.6$ & $47.2 \mathrm{e} \pm 2.1$ & $65.5 c \pm 4.0$ & $61.3 e \pm 0.9$ & $58.9 e \pm 3.7$ \\
\hline
\end{tabular}

NS - Non sterile soil; SS - Sterile soil; TBS - Tank bottom sludge; BC - Bacterial consortium; NPK - Nitrogen, Phosphorus,

Potassium solution; RL - Rhamnolipid biosurfactant solution

A a, b, c, d, e: Arithmetic means with the same letter are not significantly different from each other at 5\% probability level by Duncan’s

Multiple Range Test (DMRT)

B Standard Error. 
Table 5. $\mathrm{pH}$ of the soil during degradation of n-Alkane in oil sludge treated with different amendments for a period of up to 84 days

\begin{tabular}{|c|c|c|c|c|c|c|c|c|c|}
\hline \multirow{3}{*}{ S.No } & \multirow{3}{*}{$\begin{array}{l}\text { Amendments / } \\
\text { Days }\end{array}$} & \multicolumn{8}{|l|}{$\mathrm{pH}$} \\
\hline & & \multicolumn{4}{|l|}{$10 \%$ sludge } & \multicolumn{4}{|l|}{$20 \%$ sludge } \\
\hline & & 0 & 28 & 56 & 84 & 0 & 28 & 56 & 84 \\
\hline 1 & $\mathrm{NS}+\mathrm{TBS}$ & $7.2 a^{A} \pm 0.4^{B}$ & $7.1 c \pm 0.4$ & $6.9 d \pm 0.6$ & $6.9 c \pm 0.4$ & $7.2 \mathrm{a} \pm 0.1$ & $7.1 c \pm 0.5$ & $6.7 c \pm 0.2$ & $6.9 c \pm 0.4$ \\
\hline 2 & NS+TBS+RL & $6.9 c \pm 0.2$ & $7.0 \mathrm{~d} \pm 0.1$ & $7.0 c \pm 0.2$ & $7.0 b \pm 0.3$ & $6.9 c \pm 0.5$ & $7.0 \mathrm{~d} \pm 0.1$ & $7.1 \mathrm{a} \pm 0.4$ & $6.9 c \pm 0.6$ \\
\hline 3 & $\mathrm{NS}+\mathrm{TBS}+\mathrm{NPK}$ & $7.1 b \pm 0.3$ & $7.6 \mathrm{a} \pm 0.3$ & $7.2 b \pm 0.4$ & $7.0 b \pm 0.1$ & $7.1 b \pm 0.3$ & $7.6 a \pm 0.2$ & $7.2 \mathrm{a} \pm 0.5$ & $7.2 \mathrm{a} \pm 0.5$ \\
\hline 4 & $\mathrm{NS}+\mathrm{TBS}+\mathrm{BC}$ & $7.2 \mathrm{a} \pm 0.1$ & $7.1 c \pm 0.2$ & $7.0 c \pm 0.3$ & $7.0 b \pm 0.5$ & $7.2 \mathrm{a} \pm 0.3$ & $7.1 \mathrm{c} \pm 0.4$ & $68 b \pm 0.3$ & $6.9 c \pm 0.3$ \\
\hline 5 & $\begin{array}{l}\mathrm{NS}+\mathrm{TBS}+\mathrm{RL}+ \\
\mathrm{NPK}+\mathrm{BC}\end{array}$ & $6.9 c \pm 0.3$ & $7.3 b \pm 0.4$ & $7.3 a \pm 0.7$ & $7.5 a \pm 0.3$ & $6.9 c \pm 0.1$ & $7.3 b \pm 0.6$ & $7.1 \mathrm{a} \pm 0.7$ & $7.1 b \pm 0.4$ \\
\hline 6 & $\mathrm{SS}+\mathrm{TBS}$ & $7.2 \mathrm{a} \pm 0.3$ & $7.1 c \pm 0.4$ & $6.9 \pm 0.6$ & $7.0 \pm 0.4$ & $7.2 \pm 0.5$ & $7.0 \pm 0.5$ & $6.8 \pm 0.4$ & $7.0 \pm 0.7$ \\
\hline 7 & $\mathrm{SS}+\mathrm{TBS}+\mathrm{RL}$ & $6.8 c \pm 0.2$ & $7.2 b \pm 0.3$ & $7.1 \pm 0.3$ & $6.9 \pm 0.5$ & $6.7 \pm 0.6$ & $7.1 \pm 0.6$ & $7.2 \pm 0.5$ & $7.1 \pm 0.6$ \\
\hline 8 & SS+TBS+NPK & $6.9 b \pm 0.5$ & $7.4 \mathrm{a} \pm 0.4$ & $7.2 \pm 0.2$ & $7.3 \pm 0.1$ & $6.9 \pm 0.4$ & $7.3 \pm 0.3$ & $7.8 \pm 0.3$ & $7.1 \pm 0.4$ \\
\hline 9 & $\mathrm{SS}+\mathrm{TBS}+\mathrm{BC}$ & $6.9 b \pm 0.1$ & $7.2 b \pm 0.5$ & $7.0 \pm 0.4$ & $6.9 \pm 0.3$ & $6.9 \pm 0.3$ & $7.2 \pm 0.4$ & $7.0 \pm 0.2$ & $7.0 \pm 0.3$ \\
\hline 10 & $\begin{array}{l}\mathrm{SS}+\mathrm{TBS}+\mathrm{RL}+ \\
\mathrm{NPK}+\mathrm{BC}\end{array}$ & $6.9 b \pm 0.6$ & $7.4 \mathrm{a} \pm 0.6$ & $7.4 \pm 0.5$ & $7.3 \pm 0.4$ & $6.9 \pm 0.4$ & $7.3 \pm 0.1$ & $7.5 \pm 0.4$ & $7.2 \pm 0.2$ \\
\hline
\end{tabular}

NS - Non sterile soil; SS - Sterile soil; TBS - Tank bottom sludge; BC - Bacterial consortium; NPK - Nitrogen, Phosphorus, Potassium solution; RL - Rhamnolipid biosurfactant solution

A a, b, c, d, e: Arithmetic means with the same letter are not significantly different from each other at 5\% probability level by Duncan’s Multiple Range Test (DMRT)

B Standard Error. 
Table 6. Significance level for the different parameters tested within our treatments computed by Duncan's Multiple Range Test (DMRT)

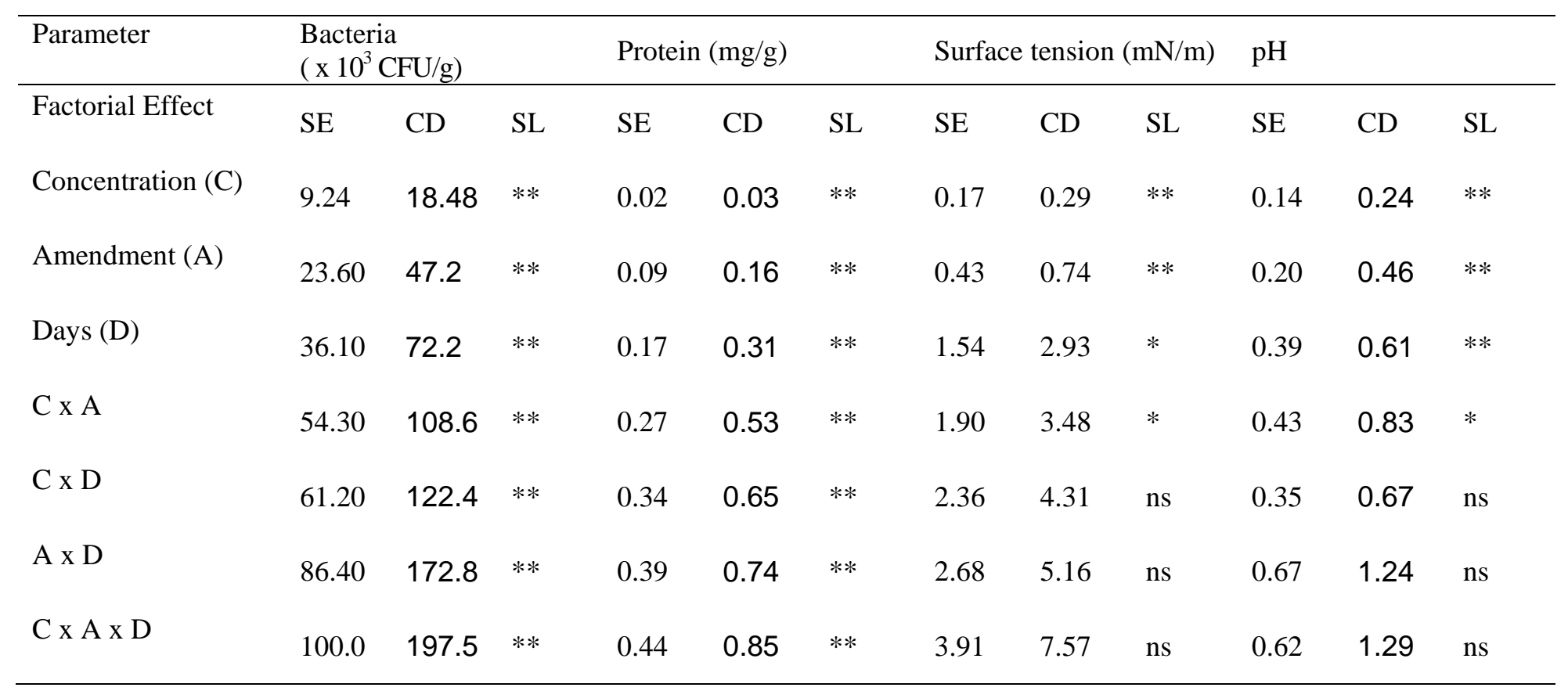

SE - Standard Error; CD -Cumulative Difference; SL - Significant level * Significant at 5\% probability level; ** Significant at 1\% probability level; ns - not significant at $1 \%$ or $5 \%$ probability levels 


\section{Figure Captions}

Fig 1. n-Alkane degradation in nonsterile soil with $10 \%$ of tank bottom sludge and $\mathrm{BC}+\mathrm{NPK}+\mathrm{RL}$ at various time intervals

Fig. 2. n-Alkane degradation in nonsterile soil with $20 \%$ of tank bottom sludge and $\mathrm{BC}+\mathrm{NPK}+\mathrm{RL}$ at various time intervals

Fig 3. n-Alkane degradation in nonsterile soil with $10 \%$ of tank bottom sludge and $\mathrm{BC}+\mathrm{NPK}+\mathrm{RL}$ on 56th day of treatment

Fig 4. n-Alkane degradation in strile-sterile soil with $10 \%$ of tank bottom sludge and $\mathrm{BC}+\mathrm{NPK}+\mathrm{RL}$ on 56th day of treatment

Fig 5. n-Alkane degradation in nonsterile soil with $20 \%$ of tank bottom sludge and $\mathrm{BC}+\mathrm{NPK}+\mathrm{RL}$ on 56th day of treatment

Fig 6. n-Alkane degradation in strile-sterile soil with $20 \%$ of tank bottom sludge and $\mathrm{BC}+\mathrm{NPK}+\mathrm{RL}$ on 56th day of treatment 


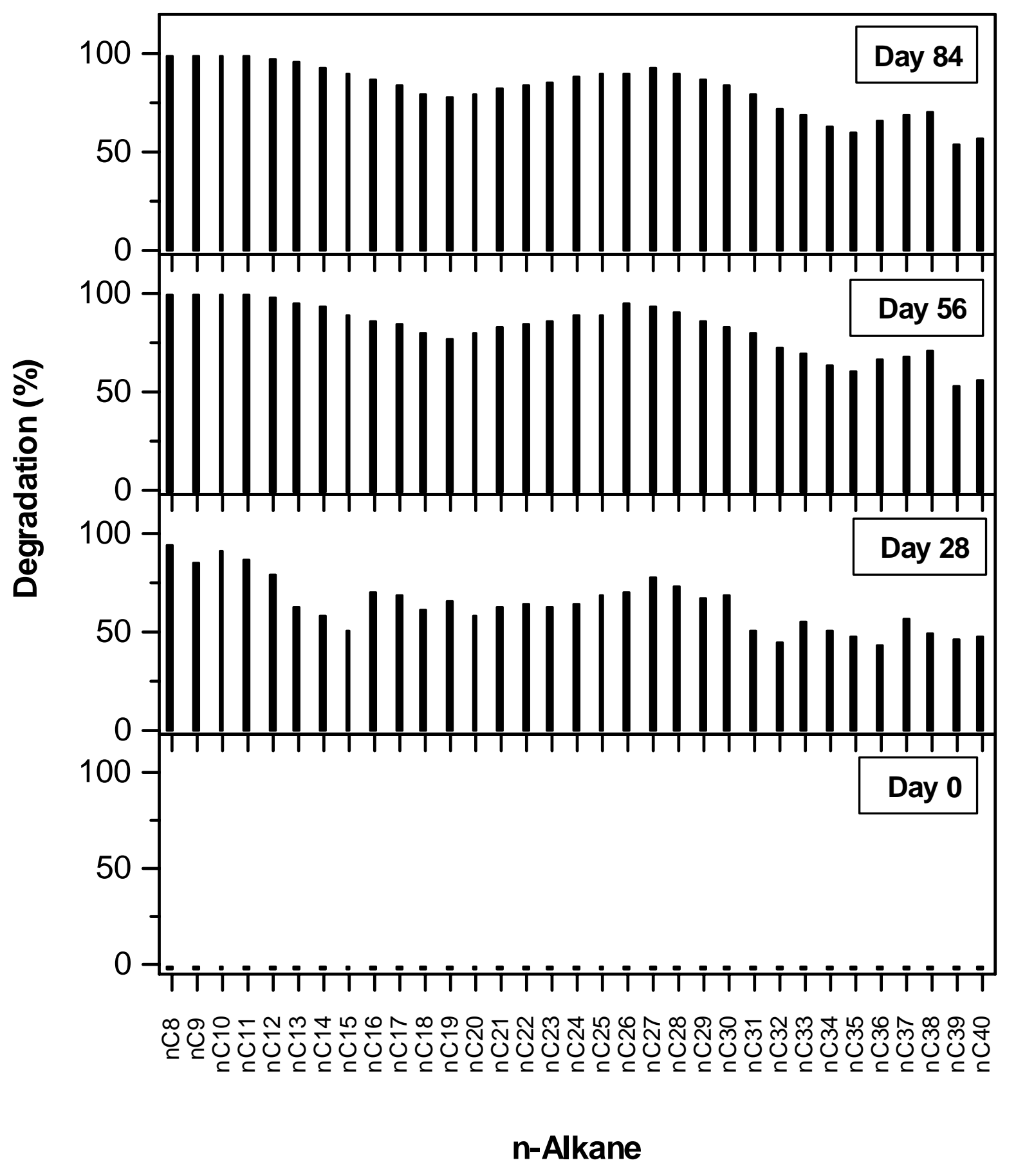




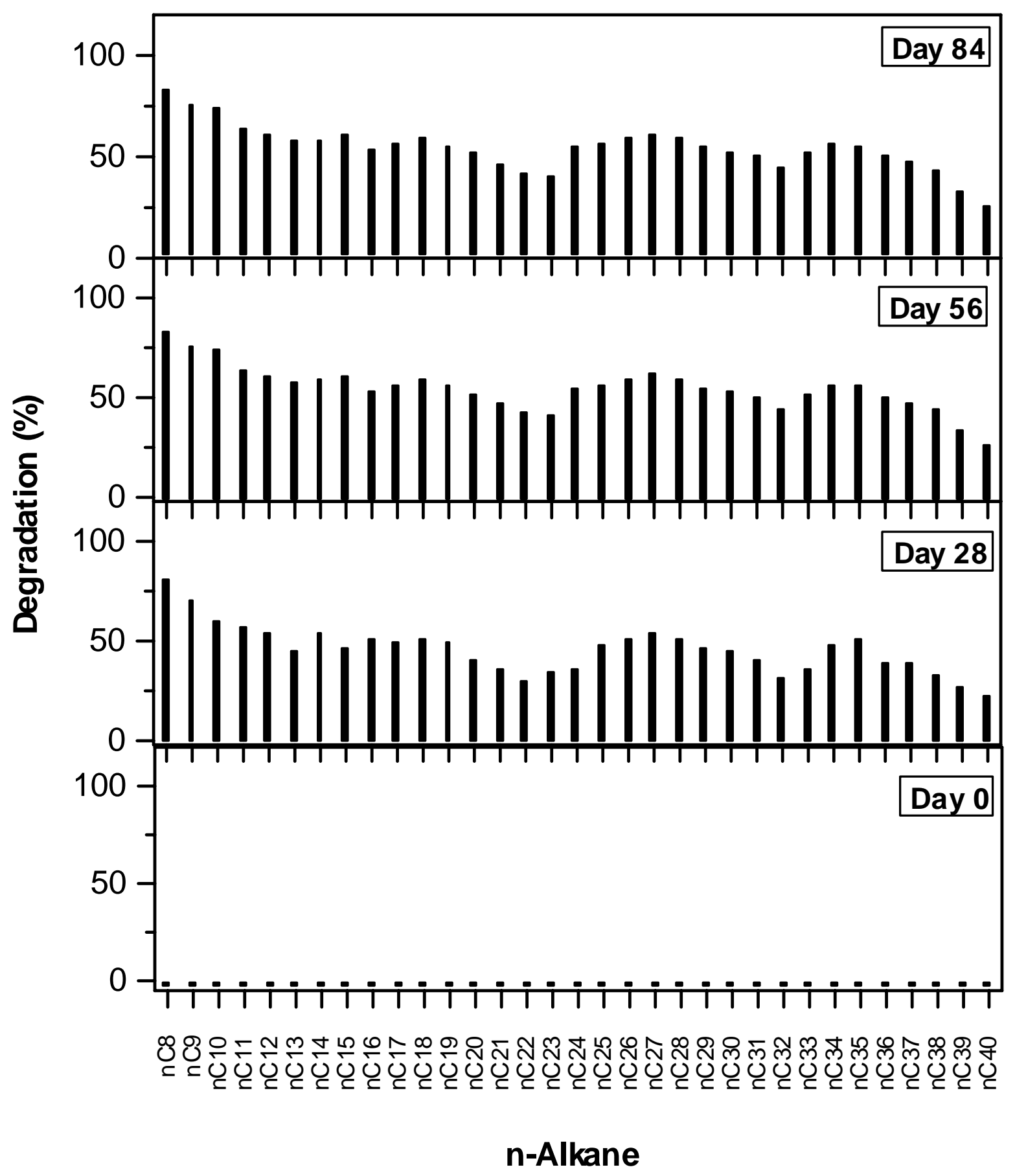




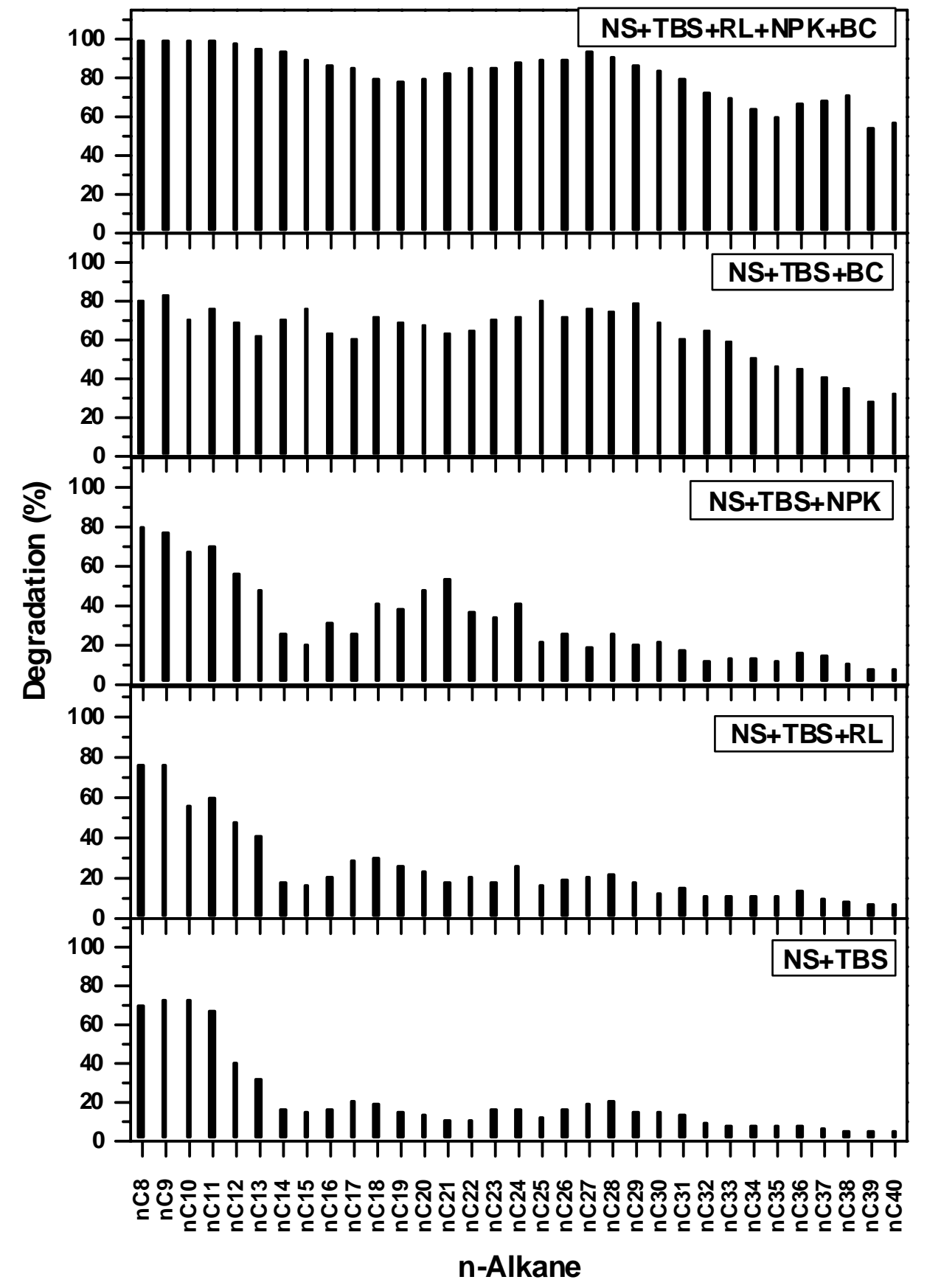




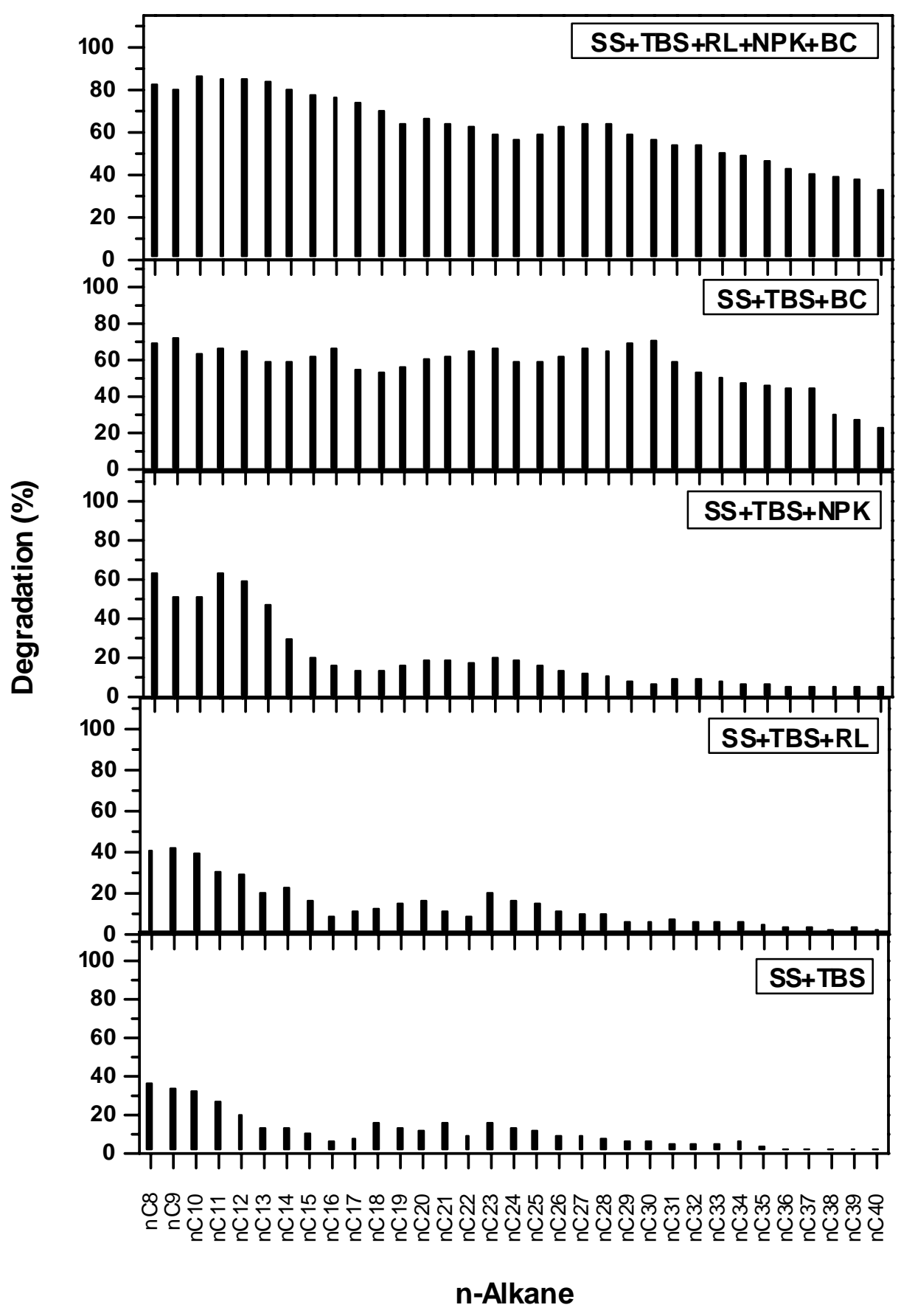




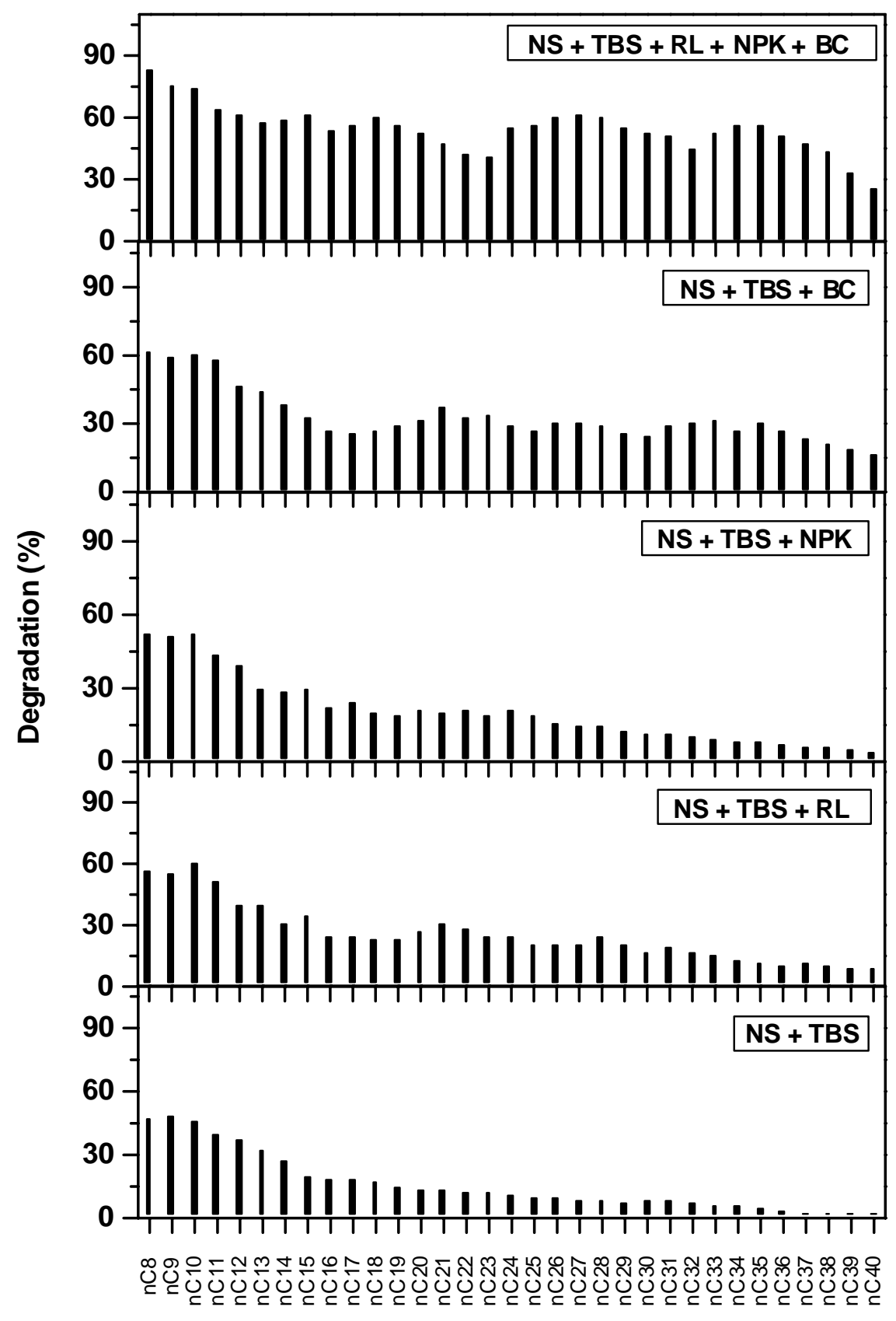

n-Alkane 


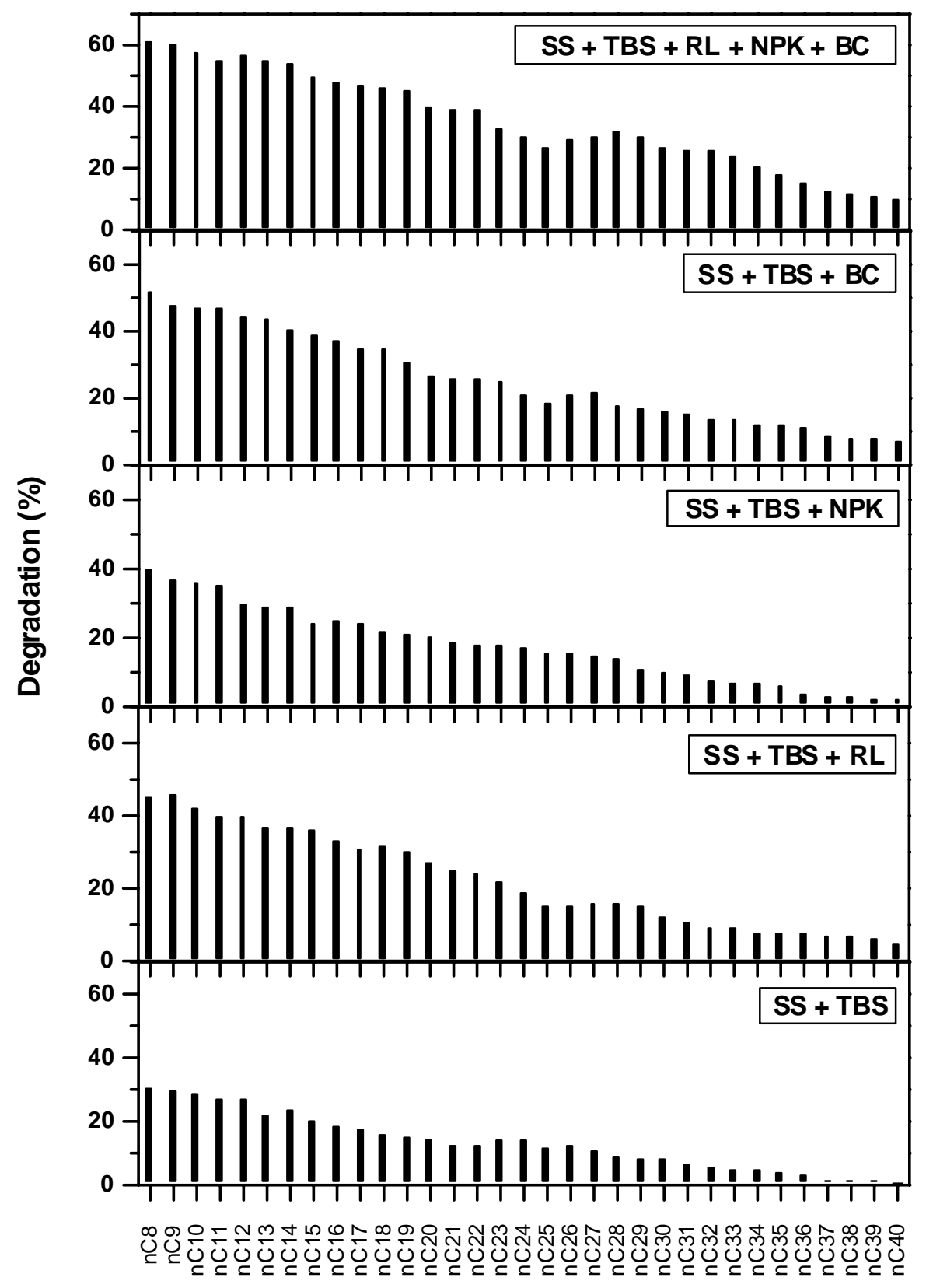

n-Alkane 